PRODUCTION

ENGINEERING

ARCHIVES
2015, Vol. 9, No.4, pp 30-34

ISSN 2353-5156

ISSN 2353-7779 (print version)

(online version)

Article history: $\quad$ Received: 22.10.2015

\title{
Eliminating waste in the production process using tools and methods of industrial engineering
}

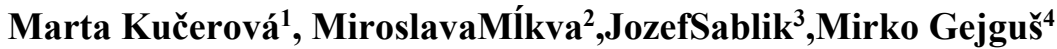 \\ ${ }^{1}$ Doc. Ing. PhD., Slovak University of Technology in Bratislava, Faculty of Materials Science and Technology, Institute of Industrial Engi- \\ neering and Management,marta.kucerova@stuba.sk \\ 2 Doc. Ing. PhD., Slovak University of Technology in Bratislava, Faculty of Materials Science and Technology, Institute of Industrial Engi- \\ neering and Management,miroslava.mlkva@stuba.sk \\ 3 Prof. Ing. CSc., Slovak University of Technology in Bratislava, Faculty of Materials Science and Technology, Institute of Industrial Engi- \\ neering and Management,jozef.sablik@stuba.sk \\ ${ }^{4}$ Ing., External PhD., Slovak University of Technology in Bratislava, Faculty of Materials Science and Technology, Institute of Industrial \\ Engineering and Management,mirko.gejgus@stuba.sk
}

\begin{abstract}
Companies of today must have their processes set in a way to fully use their capacities. It especially means efficient work, slimming of processes, reducing costs on quality but not at the expense of customer satisfaction. Within improving its processes they must carry out such improvements which allow them to eliminate unnecessary waste in the production process. Waste occurs in every enterprise, therefore workers should constantly search for it and eliminate it to increase productivity and reduce costs. In uncovering waste it is important to note the fact that we are searching for issues and not their cause and the guilty party to punish. The ability to identify waste and eliminate its causes may be the source of great improvements. When identifying waste we distinguish between seven types of waste and we use different methods and tools of industrial engineering to eliminate them. Based on many years of experience from organizations analyses conducted through student theses and based on the reconnaissance we carried out within resolving a research task we can state, that they include e.g. $5 \mathrm{~S}$, SMED etc.
\end{abstract}

Key words - eliminating waste, seven types of waste, tools and methods for eliminating waste

\section{Introduction}

An effective management of quality management results from management and optimization of all processes in the organization and it is one of the most important roles within the management of the whole organization. It has a significant impact on the economic result, on ensuring competitiveness, on meeting customers' needs, development, growth and on a new direction of the organization.

The market environment, which is now full of turbulent changes in all fields of social life and influenced by globalization, creates a completely new set of conditions for industrial enterprises and their activities. To ensure that enterprises are able to respond to the changes and to secure long-term sustainable development, it is necessary to optimize their performance 
significantly. In addition, finding a satisfactory solution for this problem is complicated because of the fact that the growing influence of globalization not only refers to the macro-economic environment, but it also influences significantly processes inside the organization (GYURÁKBABELOVÁ, VAŇOVÁ, 2014).

Removing factors, which prevent fulfilling notional goal, plays an important role. Waste is a fundamental issue in every organization, therefore it is strategically important to remove, or minimize, this unwanted problem.

In order to reduce waste, organizations extensively use available methods to prevent waste in production, which, if applied correctly, are able to eliminate waste in all stages of development and production. Applying these methods does not eliminate all types of waste, but correct use of selected methods can reduce them to an acceptable level.

\section{Waste in the production process}

Production in the company is part of the process of transforming production factors into products (goods and services), and this transformation is conditioned by a number of other processes and impacts of external and internal environment.

The production process (PP) can be characterized as a creative process, the function of which is the creation of utility values and which represents the main activity of the company.

Waste (loss) means any action (activity, process, cost) which is carried out in the production process or in the implementation of services and which does not add any value to the product and increases its costs. (KŘIVÁNEK, 2009)

Any company, which wants progress, must get rid of activities, which have a negative impact on the efficiency of the company's operation. It means to remove deficiencies (Fig. 1), called „3MU“ as referred by Japanese managers.(KADÁROVÁ, 2012)

These activities consist of:

$>$ Muri - surpluses, overloading,

$>$ Muda - losses, waste,

$>$ Mura - uniformity, deviations.

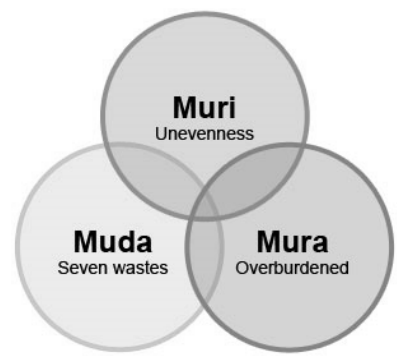

Fig. 1. Japanese words forming $3 M U$

Source: Own case study

By the lean manufacturing philosophy, we try to eliminate any waste, called in Japanese - muda. The term muda refers to those activities that do not add value. Muda at a workplace Has seven categories (BEŇO, 2011):

$>$ Muda of over-production, when a greater production of products is produced then is required by customers. Overproduction leads to wasting of materials, energies and human work.

$>$ Muda caused by unnecessary stock- this type of waste is caused due to overproduction and purchasing for storage or storage of spare parts, not finished goods and finished goods. These items unnecessarily take space and require additional costs.

$>$ Muda caused by defects - Whenever defects occur, extra costs are incurred reworking the part, rescheduling production, etc.

$>$ Muda caused by unnecessary movement of employees connected with the efficiency of their work causing a waste of physical power e.g. when removing staff to get spare parts

$>$ Muda caused by inappropriate processing, use of the wrong technology can cause the deficit because of long production launching times and long working operation times.

$>$ Muda caused by waiting - wasting in consequence of lack of components, consumables and equipment or because of a damaged machine or unstable production.

$>$ Muda caused by transport - transport is an inseparable part of the production processes which cannot be removed, however it does not give any value to the final product and this is why the aim is to reduce it to the lowest possible level. 


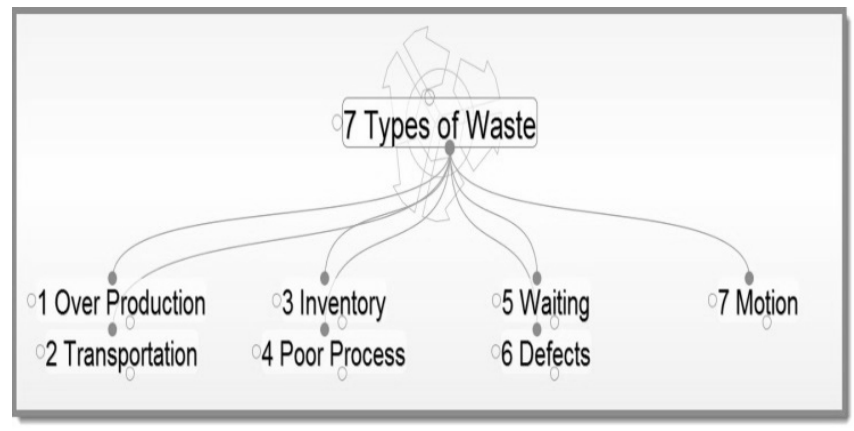

Fig. 2Seven types of waste

Source: Own case study

\section{Tools and methods to eliminate waste in the organization}

An important thing for every organization nowadays is to make profit, i.e. to improve the ratio between earned and invested money. This consideration is based on the fact, that if resources (money, labour, material, etc.) are used more efficiently, the whole process of making profit and supporting competitiveness of the organization will be enhanced. The organization should therefore try not only to analyse the waste but also to eliminate it with correctly chosen tools and methods.

Two method groups are used to eliminate waste in practice (KOŠTURIAK, FROLÍK, 2006):

1. Basic methods are methods aimed at a mostly narrow set of issues of the production system. The result of their use is a substantial process improvement. They are mostly simple, they bring first useful results in a short period of time and they are easily assessed. They are the basis for improvement. It belongs among them.

2. Complex methods are methods which combine basic methods into a whole and are aimed at a wider issue area.

The next section describes the selected tools that are most often applied in Slovak organisations. We approached this on the basis of long- term experience of the analysis of individual organizations that are performed by students' final papers and on the basis of a survey, which we conducted in the framework of the research project.

\section{TPM - Total Productive Maintenance}

TPM focuses on the involvement of all employees in activities that aim to minimize disagreements and misfits. It is also about overcoming the traditional way of dividing staff into who works on the machine and who repairs it. It is considered that the worker who operates the machine has a chance to capture abnormality in his work and potential sources of future equipment failures via TPM operational teams in the workplace (KOŠTURIAK, FROLÍK, 2006).

\section{SMED - Single Minute Exchange of Dies}

SMED is a systematic process to minimize downtime, i.e. waiting time (preparation) of working place between treatments of two following different types of products (production batches). It is a method to decrease the time of type casting of production facilities. For example it means to shorten time to replace the press mold, type casting of production line or type casting of chip-forming machine tool, etc. It is usually carried out in a team by organizing several workshops.

The whole process of this method is based on a thorough analysis of type casting, which is carried out mostly by observation at the workplace. Radical shortening of times of type casting from several hours to a few minutes is reached by the gradual elimination of waste from the type casting process, by change of type casting organization, standardization of the type casting process, team training, special aids and technical adjustments of the machine. This method is usually used at narrow workplaces, where type casting is carried out frequently and times of type casting represent significant losses from the machine or line capacity. SMED method is also often part of the TPM program.

\section{Method of 5S improvement}

5S method comes from Japan. It was first implemented in the Japanese automotive industry, where it was used to support Lean management tools. By using the $5 \mathrm{~S}$ we identify unnecessary waste in the organization and then it is easier to detect problems in the workplace. The workplace is safer and easier to organize, workers perform their jobs more effectively in a clean environment, stocks are smaller and this allows faster control. 
The $5 \mathrm{~S}$ method is the application of the 5 steps following each other (see Fig. 3) (SINAY A KOL., 2007):

$>$ Seiri (Sort): department of unnecessary things in the workplace and their removal

$>$ Seiton (Stabilize): the arrangement of all the things that remain in the workplace after the first step in a transparent manner,

$>$ Seiso (Shine): maintaining a clean working environment,

> Seiketsu (Standardize): implementation of standards and the continuous implementation of the previous steps

$>$ Shitsuke (Sustain): building self-discipline

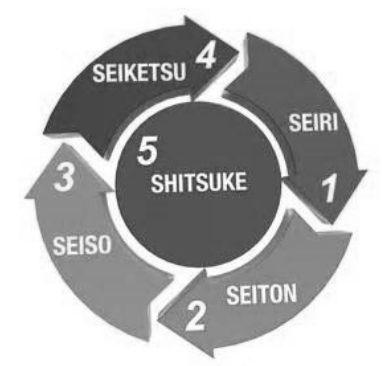

Fig. 3 Five steps of Methods 5 S

Source: Own case study

\section{Lean Six Sigma}

Recent trends in quality management philosophy suggest combining Six Sigma with the Lean method. The Six Sigma method is an effective tool for improving the quality of processes. The Lean method has efficient tools which speed up processes by eliminating losses and wastage. Rapid improvement requires both approaches and their connection is necessary for the following reasons:

Lean processes cannot go under statistical control, Six Sigma alone can not dramatically improve process speed or reduce the need for capital investment.

The application of Lean Six Sigma is also related to the reduction of production costs. Companies are trying to reduce production costs while maintaining the desired properties of the products required by customers. Quality is thus found not only in the product but also in all processes that are performed in the company. It is important to invest in improving process capabilities and to expedite the process. Streamlining of processes has a significant impact on the quality of outcomes, either in terms of cost, time and quality.

Application of Lean Six Sigma helps to increase profits. It is the market that determines the retail price and not the company. Often the only way to increase profits is to reduce costs. Lean Thinking (Lean) is to eliminate everything that does not bring value to the customer and everything that does not add value to the product, it also eliminates variables that increase the cost of production. Reduction of process time and the varying duration of a process are as important as the reduction of variability in quality (KUČEROVÁ, MĹKVA, RUSKOVÁ, 2013).

Approaches to improvement based on Six Sigma and Lean in recent years have proved effective in successful companies. The application of these concepts is particularly useful where there is a strong customer orientation, cost, quality, time and performance processes. The integration of these two principles is logical and practice can bring dramatic improvements as it is indeed possible to achieve lean processes without statistical control of variables since it is not possible to achieve a 6 Sigma process level without optimal flows and the elimination of waste.

\section{Just in time}

The concept of production management Just in Time was created and applied in the management of production since the early seventies in Japan, the USA and Western Europe. It shows Effort, primarily the effort to eliminate waste throughout the whole production process, from the purchase of materials and semi-finished products, to the distribution of finished products. Production using the principles of Just-InTime means to produce required types of products in the required quantities, in a required time, while ensuring "one hundred percent" quality, so that it is possible to remove the reasons for which the inventory must be maintained (MLKVA, KUČEROVÁ, VEČERA, 2012).

\section{Kaizen}

Kaizen means improvement in the production, focused on customers, improvement of all processes in the value chain of business activities with concurrent cost reduction. Its base is a mass initiative of operatives supported by an effective staff motivation 
system. The overall effectiveness of the management of the company is based just on the achieved productivity of work, which is monitored through staff performance. Due to this fact, it can be stated that the Kaizen method is focused primarily on operators and their performance, because the operators are cocreators and bearers of the company values (TEPLICKA).

Kaizen is based on certain guiding principles:

- Good processes bring good results

- Go see for yourself to grasp the current situation

- Speak with data, manage by facts, work as a team

- Take action to contain and correct root causes of problems

- Kaizen is everybody's business, and much more

\section{Conclusions}

Currently, organizations are forced to reconsider their status and establish effective management systems. An Integrated management system is based on the principles of process management, which is based on a continuous management of changes. The interest in maintaining and improving quality of products, the environment, and safety at work is increasing. New modern theories of management thinking and acting prioritized the application of synergistic effect. Integrated Management Systems of organizations are a very convenient way of creating a system that takes into account not only the quality of products and services, but also the attitude to the environment and health and safety at work. Such a system effectively supports the maximizing of market value and the growth of the organization.

It is obvious that in today's competitive environment each organization wants not only to survive, but also to progress and therefore it must examine its processes and minimize waste, which may be achieved by application of tools and methods for waste reduction. Waste is everything which does not bring value to the company and it highly contributes to the money spent in vain, therefore every company has to get rid of all activities, which have negative impact on its effective operation.

\section{Acknowledgement}

The paper is a part of submitted VEGA project1/0448/2013 "Transformation of the ergonomic program into the structure of company management by integration and application of QMS, EMS and OHSAS"..

\section{Literature}

1. BEŇO, R. (2011): Plytvanie (Muda) na pracovisku $\mathrm{z}$ hl'adiska ergonómie. In: Nové trendy $\mathrm{v}$ manažérstve kvality [elektronický zdroj]: 4. ročník medzinárodného vedeckého seminára, 12-13 apríl 2011, Trnava- Trnava: AlumniPress, 2011. - ISBN 978-80-8096-143-5.- S. 3338

2. GyURÁK BABELovÁ Z., VAŇOVÁ J., 2014 Crucial Role of Corporate Culture to Align Organizational Goals with Economic Success. In The Electronic Journal of Knowledge Management. Vol. 12, iss. 4 (2014), s. 241250.ISSN 1479-4411

3. KADÁrOVÁ J. (2012): Wastage in industrial enterprise. “ [online]. [cit. 2015-08-31]. Dostupne na nete: http:/www.sjf.tuke.sk/kpiam/TaIPvPP/2012/index.files/ clanky/46\%20Jaroslava\%20KAdArovA\%20Plytvanie.pdf

4. KoŠturiak, J., FrolíK, J.(2006) Štíhlý a inovativní podnik. Praha: Alfa Publishing, s.r.o., 2006. 237s. ISBN 80-86851-38-9

5. KuČErovÁ, M., MĹKva, M., RuskovÁ, D. (2013) Lean Six Sigma implementation in industrial companies. In Quality Issues and Insights in the 21st Century. Vol. 2, No. 1 (2013), s.46-52. ISSN 2029-9575

6. MĹKVA, M., KuČErovÁ, M., VeČĚ̌A, P. (2012) Application of tools and methods within "Lean manufacturing". In Carpathian Logistics Congress 2012:, Czech Republic. 1. vyd. Ostrava: Tanger, 2012, s.[6]. ISBN 978-80-87294-33-8.

7. SinAY, J. A Kol:(2007) Nástroje zlepšovania kvality. Prešov: ManaCon, 2007, ISBN 978-80-89040-32-2.

8. TEPLICKÁ K.: Kaizen - kvalita versus 3 „MU“ [online]. [cit. 2015-08-31]. Dostupné na internete: http://katedry.fmmi.vsb.cz/639/qmag/mj34-cz.htm

9. ŠMIDA, L. 2012. Príspevok (k vízii) spoločenskyužitočného a zodpovednéhopodnikania $v$ kontexteudržatel'néhorozvoja[Diploma Thesis]. MTF STU Trnava 